Crossroads 5/2014, pp.4-15

Dorota Guzowska

The University of Bialystok

\title{
A Conflict of Wills. The Seventeenth-Century Diarist Isaac Archer and His Father
}

\begin{abstract}
Isaac Archer (1641-1700) was a godly man, an Anglican minister, a good father to his nine children and the son of a possessive father. The order in which his life roles are listed here is not random. For a considerable part of his life he kept a diary in which he recorded the many struggles with his sinful nature and presented himself as a man whose priority was to submit to the will of God. His humbleness was frequently and most painfully tested in the context of his parenthood, but it was the challenges that he faced in the relationship with his own father that seemed to have had the greatest impact on his spiritual as well as daily life. This article is a portrait of this very turbulent relationship between a seventeenth-century adult son and his strong-willed father.
\end{abstract}

Keywords: Isaac Archer, diary, relationship, conflict.

\section{Parents and their adult children}

Family life, both in the present day and in the past, has been governed by certain norms regulating parent/child relationships. Recent studies clearly show that the model of formal, unaffectionate contacts between parents and their offspring in early modern England, described by Lawrence Stone in the 1970s (Stone 1977), cannot be universally applied to all English families, and that there was, in fact, much space in family life for love, affection, care and commitment (Pollock 1983; Ozment 1983; Macfarlane 1987, Houlbrooke 1990; Woods 2006; Fletcher 2010). This new interpretation of historical evidence does not, however, invalidate completely the traditional view of early modern parenting. Affectionate and caring or not, parents were seen as agents of God's will, and their roles as nurturers, disciplinarians, providers and educators had a divine mandate. The children, in return, were obliged to honour and obey their parents because obedience to them was obedience to God (O'Day 1994: 4649). Parents' role was to prepare their children to live in the world, while children's duty was to follow the prescriptions and demands of their parents (Ben-Amos 2000: 292). But how long was this supposed to last? How long were parents obliged to be involved in the lives of their children, and to what extent were adult sons and daughters supposed to meet their parents' expectations? What was the nature of parental/filial love in the period beyond adolescence and early youth? Theoretical traditions such as attachment theory, family solidarity theory, exchange theory, bioevolutionary approaches, social integration theory, and psychoanalytic theory, used in studies on contemporary family life, emphasize the importance of the parent/child relationship over the course of life. Children's financial independence or physical distance are seen as less important than a distinctive history, a set of experiences, carried by family members and connecting them throughout their lives (Umberson 1992: 664-665). 
Studies on the issue of parent/child relationships in early modern Britain, some of which are referred to in this article, tend to focus on the period between infancy and the moment children left home for service, apprenticeship or marriage. In studying relationships between adult children and their elderly parents, earlier historians focused on the questions of inheritance and the care of the elderly, and even when the psychological aspects of these relationships were addressed, it was usually done in the broader context of both parties' material well-being (Thomas 1976; Wall 1987). Elizabeth Foyster notes that historians tend to see marriage as "the point of no return when the break from parental control was completed" (Foyster 2001: 314). In contrast to the prevailing view of "loose" and "shallow" relationships between parents and their adult children, Foyster showed that the bond, although changed in nature, was not entirely severed, and her claim is that sources provide enough evidence of the significant presence of parents in the married lives of their offspring. She wrote, "It is clear that the nature of the parent/child relationship was one that was constantly changing. Marriage was just one point in the life cycle which could mark a shift in parent/child relations, but this did not signal the end of shared experience" (Foyster 2001: 317). Foyster emphasized the involvement of parents in initial marriage negotiations, in the financial affairs of a new couple, in the upbringing of grandchildren, as well as in resolving marital crises.

Regardless of their children's age, parents also remained emotionally committed, and usually found it very distressing when their children's marriages or careers failed. A number of early modern ego-documents: diaries, autobiographies, letters written by parents representing various sections of society, are a testimony of their concern for their children's well-being, even when said children were independent adults. However, commitment, or sometimes even more active involvement in the lives of grown-up children, did not mean that all parents expected the same degree of obedience as they had when their daughters and sons were children and adolescents. Some sources, in fact, show parents quite helpless in the face of problems caused by their adult children's refusal to follow parental advice. Although they saw and bemoaned their offspring's misguided decisions, rarely were these viewed as sheer instances of insubordination, but rather as painful reminders of their own failure to prepare the children for adulthood (cf. Henry Newcome's diary and autobiography, Ralph Josselin's diary). The question arises as to what feelings and emotions were experienced by adult children spreading their wings and, in their attempts to live on their own, sometimes rejecting their parents' will. Another question is what impact the child's struggle for independence had upon the parents themselves and upon the relationship with their adult offspring.

\section{The diary and its author}

An answer to this question will be sought in a diary written by Isaac Archer (1641-1700), a father of nine children and himself the son of a very possessive father. What is offered in this article is a picture of a parent-adult child relationship from the perspective of the latter, with special emphasis on the emotional side of it. The diary covers the whole of Archer's life, from 1641 to 1700, but the first entries were not written until 1659 (Archer 1994: 44). Archer's diary is one of many similar seventeenth-century texts created by individuals who committed to paper their religiously motivated need to search and examine their souls. The second half of the $17^{\text {th }}$ century in England was a time of rapid growth in the popularity of autobiographical writing, with spiritual diaries and autobiographies being the most popular forms, especially among members of dissenting groups (Delany 1969: 27-106; Ebner 1971; Glaser 2001: 46-49). As can be concluded from Isaac Archer's own text, his non-conformist father kept such a spiritual diary, and his prompting became an important factor in his son's decision to write an account of his religious experiences (Archer 1994: 43-44, 124-125). Isaac 
Archer's diary falls into the category of Anglican spiritual life-writing, but it is also a record of his doubts concerning the practices of the Church of England; doubts which were consistently fed by his father.

The editor of Archer's diary suggests that the manuscript on which the publication was based, the only surviving manuscript copy of the diary, is in fact a later version of earlier drafts (Archer 1994: 6-7). One characteristic structural feature of Isaac Archer's diary is that the author was in the habit of delaying writing about important events in his life until he was ready to reflect upon these events and upon his immediate responses to them and, as a result, evaluate those responses. Noting this feature is very important from the point of view of this study because this method of writing entails some degree of reworking, reinterpreting, and self-censorship. Choosing between what should be revealed and what should stay concealed is, of course, typical of any autobiographical writing, and Archer's creation of a specific image of himself in the diary is natural (Glaser 2001: 16-17). His wish to do so is even more understandable in the light of the fact that he wrote with readers in mind. The vision of his diary being read by someone else came to him as a disturbing realization soon after his father's death, when he found some very intimate details of William Archer's life among his personal papers. This "could have made [Isaac] wary of committing everything to paper" (Archer 1994: 9). On the other hand, the awareness that he was writing 'for the world' made him fashion his life stories according to norms and patterns this 'world' accepted. An important task of today's reader of Isaac Archer's text is to find out what hid behind selfcreation and convention. Archer's story appears to be a good illustrative example supporting the thesis that although convention made adult children appreciate their parents' involvement in their lives, in reality it could have been a source of conflict and frustration.

The following biography of Isaac Archer is based on the information he left in his diary. The graduate of Trinity College, Cambridge was born in the county of Suffolk, where he spent his whole adult life as a minister. His father, William Archer, was a non-conformist lecturer at Halstead and Colchester, a man with a difficult, volatile character, whose high expectations were the source of Isaac's frustration. Their relationship, however, was very strong, probably because Isaac's mother died when he was only 8, so his father became the sole provider of parental care. Soon after, two of Isaac's siblings also died. Writing about this traumatic experience in his diary, Isaac Archer remembered his grief-stricken, melancholic father, who found it extremely difficult to comfort himself after the loss. It is possible that it was William's prolonged mourning and detachment from the two surviving children (Isaac and his sister Mary) that was responsible for the combination of yearning and rebelliousness that characterized Isaac's attitude to his parent. Four years after Isaac lost his mother William Archer boarded him at Halstead school, and then sent him to London to learn the trade of linen drapery. In the meantime, however, Isaac underwent a radical religious conversion and decided to become a minister. Although his father initially opposed the idea on the grounds of Isaac's heavy speech impediment and the fear that a university education would in fact divert his son away from godly life, in 1656 Isaac was eventually admitted to Trinity College, Cambridge.

Since 1660 he had been constantly admonished in letters from his father not to succumb to the charms of post-Restoration Anglicanism, but he found it increasingly difficult to follow this advice, as conformity held out the prospect of financial independence. One of Isaac's major concerns throughout his school, apprenticeship and university years was lack of money. Although he was his father's only surviving son, and William's financial situation was fairly secure, he was never sufficiently supported. He did not seem to fully understand his father's reasons for refusing him material provision, but it must have been a painful experience because many years later when he wrote about his childhood, one of the most vivid memories 
was that "when I went to schoole my father kept mee bare of clothes, and as for money I had none as the rest had" (Archer 1994: 49). It is perhaps due to this humiliating experience that Isaac was so determined in his adult life not to owe anything material to his father, and this determination informed most of his crucial decisions.

In 1662, Isaac was ordained an Anglican priest against his father's wish. Three years later, persuaded by his father to abandon the Church of England, he unofficially resigned from ministry in his parishes of Wicken and Chippenham. However, the prospect of becoming financially dependent on his father again was a decisive factor in his return to ministry after a three-month break, although he never stopped having serious reservations about the postRestoration church settlement (mostly because of his disillusion with its clerics, some of whom were his fellow students in Cambridge - Archer 1994: 65, 67, 74). His father's immediate reaction was not recorded in the diary, but Isaac's choice must have been a blow to him since he decided to punish his son by disinheriting him in his will. Their relationship became even more stormy after Isaac's marriage, concluded without William Archer's full consent. He was willing to approve of the bride, Anne Peachy, as long as his son could secure a safe living. Isaac's hasty marriage took his father by surprise. He was dissatisfied with the dowry offered by Anne's father, suspected her family of using the marriage as an opportunity to seize his estate, and was generally disappointed that his son did not invite him to attend his marriage ceremony. Although most misunderstandings were subsequently cleared up, it did not suffice to have William Archer change his will.

This uneasy relationship inevitably shaped Isaac's own experience of fatherhood, which was not for him unalloyed bliss and joy. During the fifteen years of his marriage to Anne he buried at least eight children. On the day of his death in 1700, only one child, his daughter Anne (born in 1670), was still alive. Isaac Archer's diary is thus a record not only of his relationship with his father, but also of an experience of fatherhood that was fraught with conflicting emotions, from delight and joy, through pride, to helplessness and grief. His religious persuasion made him see the hand of God in all this and interpret all the misfortunes he experienced as a father as divine retribution for his own filial sins.

\section{Isaac Archer and his father: conformity and marriage as bones of contention}

In the diary, the stories about arguments over Isaac's decision to conform with the Church of England and then to marry against the father's will are told in words that reveal deep frustration and are the expression of Isaac's dilemmas. On the one hand, writing about his "good father", "dear father", a father who was "more eminent than I may modestly say" (Archer 1994: 44), he maintained the father's image he, as a cleric, felt bound to uphold. On the other hand, fragments of the diary relating to William Archer are abundant in emotionally loaded words and phrases, such as "displeased", "ashamed", "unnatural carriage", "worse", "snared", "fight against", "lost", "troublesome", "arbitrary", "threatenings" [sic], "provoke", "misunderstand", "sorry", "angry", "forcing", "refuse", "distance", "undutiful”, "hardening my heart", "disobedience", "reproof", "sin", "devil", "afraid", "could not trust", "enraged", "passion", "called me names", "his impatient and cholerick temper", "breach", "disappoint", and "enemy" (Archer 1994: 69, 72, 80-82, 86). It seems that although Isaac tried to maintain the appearance of respectfulness towards his father by writing, for example, "[...] now I doe thinke he naturally cares for mee, and then did all for my good" (Archer 1994: 82), or "my way towards my father was not good" (Archer 1994: 83), he could not help using diarywriting as a means of giving vent to his negative feelings. 
At the same time, the religious motivation of Archer's writing is clear, and the diary formally serves the double purpose of being an introspective self-analysis and a testimony to God's merciful love for a man who sinned so much against his own father. In this vein, descriptions of the worst moments in father/son relations are there to show how far Isaac Archer had changed from his impertinent disobedience to deference. Nevertheless, the diary still reveals much of his impatience caused by his father's behaviour: "Because my father kept me bare in money, although now I thinke "twas large allowance, but I wanted discretion to lay it out, I talked broadly and unbeseemingly of him, neither minding what, or to whom I spoke" (Archer 1994: 79). Probably the most candid expression of Isaac's irritation was a fragment of his diary where he wrote that he could not continue living with his father because "his deep melancholy would kill mee" (Archer 1994: 114). Elsewhere, commenting on how his father changed his mind and forgave him marrying without his consent, Isaac seemed relived but still could not help marvelling: "I know not how, my heart was inclined to love, and obey him" (Archer 1994: 117).

Fatherly affection was definitely not a thing that Isaac took for granted, and his diary reveals the pain he felt in realizing that sometimes it was offered only when deserved. Only when given a good reason would his father express warmth and liking. The very prospects of not meeting the father's expectations or of earning his displeasure made Isaac very anxious in contacts with his parent. In 1659, after two years spent in Cambridge and a number of letters in which he informed his father about his spiritual struggles, Isaac visited his family home. This is how he remembered meeting his father: "I was bashfull, and very fearfull least my father should find mee worse in discourse then [sic] in writing; I was almost ashamed to owne or speake of those things I had found in my heart before; and therefore, though I longed for more soule-counsell, omitted speaking to him" (Archer 1994: 58). Constant displeasure at his son's decisions was perceived by Isaac as a means of forcing him into absolute submission, even after he left home and embarked on arranging life on his own. At the same time, though, he appreciated that his father sometimes refrained from openly commanding him what to do and instead "for love's sake did intreat mee not to break his heart" (Archer 1994: 72).

Although Isaac was not always disposed or willing to comply, he, paradoxically, sought his father's love and approval and delighted in all the rare moments when either was shown to him. The following words reveal that the father's friendly attitude often came as something of a surprise to his son: "[he] expressed now more than ordinary love in his letters" (Archer 1994: 99), "My wife and I went to see my father, and found extraordinary kind usage, beyond my expectation" (Archer 1994: 118). It is clear that even though he wanted his father to recognize him as an independent individual, he yearned for his understanding and support, and despaired when they were not granted: "[...] he wrote mee a chiding letter which grieved mee. I confessed all my disobedience to God and him, desiring solemnly pardon from both" (Archer 1994: 115);"I wrote my father word of my marrying, and intentions to settle; and he was very angry, and threatened to reward mee in deeds; I besought God daily to worke his heart, and open his hand to mee in a way of maintenance; and to dispose my soule to obedience, $[\ldots]$ and my burden was heavy; the Lord speake peace, and make up the breach!" (Archer 1994: 117). In 1668, although he was 27, married, and living his own life, he did not find it unnatural to visit his father, enter his study and confess with tears his disobedience, and promise solemnly "to be so to him no more" (Archer 1994: 118). After all, Isaac wanted to believe that his father was the "one that would naturally care for mee as to body and soule" (Archer 1994: 53).

That unresolved conflict with his father was clearly a source of Isaac's mental suffering. There is a passage in his diary where he confides that it was a reconciliation with his father that helped him restore emotional balance: "I found my selfe much better in mind since my 
reconciliation with my father; my heart was more towards him then [sic] formerly" (Archer 1994: 119). Much of Archer's diary is a record of his desperate struggle to love and respect his father in spite of their uneasy relationship. The reader cannot help suspecting that whenever Archer praised his father for being critical of his [Isaac's] achievements as a preacher, or for reminding him of his right as a father to be informed about his marriage plans in advance, he was doing so to persuade himself that it had all been done out of selfless fatherly love. When the love-driven motivation of his father's actions did not seem apparent, Isaac always attempted to dig deeper, always trying to excuse his father, to find some good that came out of William's efforts to direct him, and to find more reasons for humbling himself before God. When he found out that his father had disinherited him, and that he and his wife "are not like to enjoy what my father was so long gathering", he explained it to himself, writing: "I have deserved this from him, who might doe what he would, with his own, and much more from God, whose hand I see in it! I hope I shall mind eternity the more for my disappointments heer! And use this as physic in regard of my soule's health" (Archer 1994: 124). Anger, displeasure, even if felt at heart, were not disclosed openly in writing. However, he found a way to give vent to negative emotions by ascribing them to others, i.e. 'the world', which, as he assured his readers, interpreted his father's decision as revenge: "the uncles were much vexed at it, but can not helpe it, only hope, in the end 'twill worke for good, which God grant for Christ's sake. Amen" (Archer 1994: 124). Sharing responsibility with others seemed a good, tried-and-tested defence mechanism, which Isaac had used before, shifting the blame for filial disobedience concerning religion onto his college friends (Archer 1994: 69). It did not, however, fully alleviate his suffering, and the whole diary bears witness to his deep sense of guilt.

In his diary Isaac Archer allowed his readers to see that despite the various moods and states revealed above, his attitude to his father did in fact change over time. Although words such as "severity" (Archer 1994: 115) and "mistrustful" (Archer 1994: 124), and passages such as "he would have mee [...] be hot or cold" (Archer 1994: 114), suggesting some level of tension in their mutual relationship, appeared in fragments relating to the time when Archer was 26 and more, they were nowhere near as dramatic as the ones he used when writing about the time when he was a young rebel. The passages that follow are significant in this regard: "I had a letter from my father, who charged mee with contradicting my selfe, and told mee that he never knew any one of such a temper and spirit. Now he thought mee in a far worse posture then before, and thought mee snared with self confidence in spiritual things, and that former convictions were wrought of, or fought against; and wished mee to see my selfe lost, that Christ might find mee" [...](Archer 1994: 81); "I dared not venture to be at his arbitrary allowance" (Archer 1994: 81); "I confesse I was sorry he was so angry, but did not feare his forcing mee home, because he was at such a distance from mee" (Archer 1994: 81); "[...] he was so enraged that in his passion he called mee such names as he never did before or since" (Archer 1994: 86); "I pleaded that from that time he left mee to my selfe" (Archer 1994: 86); "I had gotten an habit of writing sawcily to my father [...]. [I] wrote unhandsomely [as] if he had been only my elder" (Archer 1994: 86). The quotations show Issac Archer at his worst, but it is also hard not to get the impression that the two Archer men were birds of a feather.

Later in his life Isaac regretted all the bitter words that he had addressed his father with. What is more, it is evident that he deliberately remembered these difficult moments to humble himself before God. Diary writing was for him a form of examination of the conscience, with occasional invocations escaping his lips (or rather his hand): "The Lord in mercy forgive my unnatural carriage to a good father who mourned over my sinfull behavior! And I desire to make amends for the future. Amen!" (Archer 1994: 80), or "The Lord humble mee for my undutiful carriage towards him!" (Archer 1994: 81). 
In order, probably, to emphasize his own sinful nature, parallel to the descriptions of his youthful rebelliousness, Isaac created an idealized version of his father as a strong-minded, consistent, devout Christian. When in Cambridge, Isaac often wrote to his father, seeking advice in moments of despair and self-doubt. He found it more difficult to talk to him face to face about the state of his soul or "being troubled with vaine thoughts in prayer" (Archer 1994: 62), but he would open up his heart in letters to the man whom he believed to be "a most experienced Christian" (Archer 1994: 53). At the beginning of his career Isaac was presented with a book of sermons his father had preached. It helped him get through the most difficult stage before he gained some experience and fluency as a preacher. In the diary he confessed: "[...] my ambition was to imitate my father. [...] In reading his sermons I would admire his goodness, and repent that ever I slighted him, in that manner as I did of late, who was so precious a man, and so excellent a preacher. I made his zeal and fervency in preaching a pattern to my selfe, so that many wondered and were amazed that such things should come from one so young as I was" (Archer 1994: 94). The most touching passage, however, is where Isaac writes how he was overcome by emotion after reading some of his recently deceased father's papers and discovering that William Archer was, in fact, a real man with weaknesses and infirmities of the spirit Isaac knew so well from his own experience. He writes: "Who would thinke that the same vaine, filthy, lewd thoughts should be in both of us! [...] I could not have thought that ever such things had bin [sic] in his heart, who even before and then was a gracious, sincere Christian; I did not thinke any had bin [sic] so bad that way as my selfe; and thinke so still, for though the same was in him, yet he delighted not in them, but mastered them, which I could, or rather would not, a great while" (Archer 1994: 124-125).

Isaac's father was definitely not an easy man to live with, but his son was also very well aware that he himself was often the one to be blamed for much of the friction in their relationship. As he writes, "that unhappy breach betwixt my father and mee" was caused and fueled not only by William's "impatient and choleric temper", but also by his own pride, rashness and imprudence (Archer 1994: 69). Elsewhere, he chose to describe the situation by making use of religious allusions. He depicted himself as the prodigal son tempted by Satan not to humble himself before the father: "[...] 'twas often in mind to speake to him, and confesse my faulte, but Satan, through strong temptation working upon my proud nature, would not let me" (Archer 1994: 91). Operating within the same discourse, Archer writes about the day he plucked up courage and visited his father after a long break, and in an apologetic mood he made a confession that his "carriage had bin unbecoming a child" (Archer 1994: 91). In that scene the father was no longer presented as a stubborn miser, but as the Biblical father who was "full of compassion, and ready to forgive, and willing to forgett any thing of that nature, yea he was glad that I moved him to it, and shewed his love by giving mee severall things then" (Archer 1994: 91). Castigating himself for an improper attitude towards his father, Archer writes elsewhere in the diary: "[I] thinke I shall love him better as I grow wiser, and now see, and am ashamed to think how foolish and obstinate I was" (Archer 1994: 100). Eventually, he made a resolution that, even if provoked by his father's actions, he would never again let his "heart rise against him as before" (Archer 1994: 119). His selfcriticism gained momentum in 1670, when shortly after William Archer's death Isaac seems to have made several crucial discoveries while perusing his late parent's personal papers. He realized that his father had been writing extensively about their conflict and, as it transpired, he had often misinterpreted his son's intentions and reasons for disobedience. Although Isaac made it clear that he did not regret his choice of wife ("who is a blessing to mee" - Archer 1994: 125), he wrote that he wished he had had a chance to live his youth again, probably to make up for the sorrow he had caused. He concluded this passage with an exclamation: "The Lord forgive mee for Christ's sake! and doe not reward mee as I deserve, O my God! Amen" (Archer 1994: 125). 
In 1669, Isaac Archer became a father himself, and soon after the birth of his daughter he writes in his diary about the reconciliation with his father. It is never openly stated that it was Isaac's own fatherhood that helped the two men to make peace at last, but some passages in the text indicate that the younger Archer definitely learnt to understand his father better and to see his own conduct as a son in different light. This is discernible in the passage where he tried to reconcile himself to the fact that, although he had prayed for a son, his wife gave birth to a daughter. He mentioned a letter to his father in which he wrote that by denying him a long-awaited son, God "[took] away fear of such a disobedient child as I was to him [his father]". He also added that he saw it as a great sign of mercy that God did not want to "requite mee as I had served him [his father], for I considered girls are not so dangerous" (Archer 1994: 118). He had been full of foreboding about God's plans for him long before he actually became a father himself. Once, acknowledging disobedience to his father's wishes, he expressed his fear that God would "avenge thees things in mee in the same kind" (Archer 1994: 115).

Isaac Archer's father died in August 1670. His death was sudden and unexpected. Isaac was informed about it by a messenger and immediately set out on a journey to his father's house. He confessed openly in the diary: "I did not thinke it would have so grieved me, at the newes; 1st I was taken giddy etc. When I came to my mother I was so feeble I could not hold a glasse without spilling, by a strange kind of surprise" (Archer 1994: 123).

\section{Conclusions}

Isaac's relationship with his father was for him a source of conflicting emotions. On the one hand, he felt guilty of disobedience, lack of due respect, and of deliberately distancing himself from his father. He loved and missed him and keenly sought his approval. On the other hand, he felt a strong need to establish and guard some borders beyond which his father's parental authority could no longer be exercised. We learn from the diary that in his decision to conform with the Church of England and then to marry Anne Peachy, he had strong support from his fellow scholars, teachers, and friends (Archer 1994: 68, 69, 74, 78, 81, 115). One Mr Dearsly, a fellow of Trinity College, became almost like a father figure to young Isaac, and once in his diary he even wrote about him: "My father, nor scarce my tutor, for I called Mr Dearsly so..." (Archer 1994: 55). His other friends would also come to his aid when he was in need of arguments for disobeying his father on the matter of conformity: "I was told by my friends at the colledge that it was not disobedience in such things which a parent could not reach, viz. religious worship" (Archer 1994: 69). It is possible that although his real father's opinions mattered to Isaac, the fact that he had these alternative sources of social integration and support, i.e. other people who could fulfil fatherly or brotherly roles, helped him overcome doubts about whether or not he should act against William's wishes (cf. Umberson 1992: 665). In this sense, he was similar to many other young people who defended their religious choices, made to the displeasure of their parents, by "invoking a higher obligation" (Cavallo 2014: 22). Isaac Archer could thus be seen as a typical child of the Protestant Reformation with its very doctrine of "the priesthood of all believers, [...] attacking the paternalistic authority of the priesthood and undermining the heads of Catholic households", so feared by the said Catholics and so appealing "to young people seeking independence and spiritual liberation" (Brigden 1982: 38).

Early modern English writers on conduct presented marriage as "a gateway to manhood" and a means of making a man "complete". Marriage "both conferred status within the context of the household and elevated a man's position in the wider community" (Shepard 2006: 7475). In this sense, marriage marked the transition from the world of parent-dependent youth to 
the world of independent adulthood. A marital relationship provided a man with a position of power and control over subordinate members of his household, and thus could have been perceived by young men not only as a means of securing their manhood in the eyes of the world (Foyster 1999: 4), but also as a means of freeing themselves of the relationships with their parents in which they felt constricted. The fact that after several years of successful marriage Isaac still felt pangs of conscience for entering into it against his father's will indicates the existence of an unresolved conflict between his sense of filial duty and the need to control his own life. As William Archer did not make it easier for his son by disinheriting him, Isaac's frustrations, as committed to paper, appear entirely explicable. Although, formally, young people in early modern England could marry regardless of what their parents and friends advised, and parental consent to marry was not legally necessary for men over the age of 14 and women over 12 (Macfarlane 1987: 128), the case of Isaac Archer proves that "in the important matter of laying a sound economic foundation to the marriage, it was clearly wise to obtain the goodwill and support of those who might help with connections, advice and gifts" (Macfarlane 1987: 147).

Ralph Houlbrooke points out that sometimes parents' "protective solicitude made it harder for [the] children to spread their wings" (Houlbrooke 1988: 171), and emphasizes that pious clergymen were most guilty of attempting to control their adult children and, being led by their sense of religious duty, they made heavy emotional demands on their formally independent offspring (Houlbrooke 1990: 180-181). Fathers were constantly reminded that there was a higher bond between them and their children than that of blood. It was the bond of faith and of shared subjection to "a divine plan in both their domestic and religious life" (Ozment 1983: 153). Fathers were thus obliged never to cease guiding their children so that they lived in accordance with God's law. William Archer was such a father: all the more so because of his six children Isaac was his eldest and only surviving son. Although the "primogeniture that tended to reinforce the bond between fathers and their eldest sons" among the gentry did not play such an important role among clergymen (Houlbrooke 1990: 180-181), William Archer's relationship with his male heir, and his deep involvement in his son's affairs revealed some typical characteristics of close but often strained relationships between fathers and the heirs to their estates. William's refusal to help his son financially as long as he worked as a conformist minister, and his repeated attempts to lure Isaac away from his vocation by the prospect of allowing him money and goods the moment he gave up his ministry and returned home may have been a means used by a godly, non-conformist father to save his son's soul (which Isaac many years later acknowledged in his diary). However, they may also have been a less noble means used by a manipulative father who was well aware of the power he had over his son and potential heir. Isaac's vehement opposition to his father's attempts to arrange his life must be therefore viewed as a spiritual struggle and the tragedy of a young man who sought to articulate his manhood through rebelling against his parent, but was well aware that in the long run his insubordination would not prove, literally, costeffective.

Although early-modern fathers were advised to suppress the need to spontaneously show warmer feelings towards their children, at critical moments they were often unable to fully control their emotions, traces of which can be found in their writing (Fletcher 2010: 37-38, 61, 129). As a father, Isaac Archer seemed to have been very affectionate and caring to his children when they were small, and loving and supportive to his only surviving daughter in her married life. It cannot be ruled out that his attitude would have been different had any of his sons lived to adulthood, and it is not impossible that he would have established the same emotionally-charged communication strategies that had made the relationship with his own father so difficult. However, judging by his patient conduct towards his somewhat wayward 
son-in-law, it is somewhat likely that he would have made a less despotic father to his adult sons. Interestingly, although his father's domineering manner evoked negative feelings and occasional outbursts of open rebellion, the very principle of filial subordination was never questioned in the diary. On the contrary, it seems that the aim behind writing about this particular aspect of Isaac's life was to warn the potential readers of his diary by showing that his acts of disobedience were never committed without scruples and, in the long term, they proved harmful spiritually and, in a more mundane sense, cost him material security.

\section{References:}

Archer, Isaac. 1994. The Diary of Isaac Archer, 1641-1700. ed. by M. Storey, Two East Anglian Diaries, 1641-1729. Isaac Archer and William Coe. Suffolk Records Society, vol. XXXVI, 43-200.

Ben-Amos Krausman, Ilana. 2000. "Reciprocal bonding: parents and their offspring in early modern England", Journal of Family History, vol. 25, no. 3, July, 291-312.

Brigden, Susan. 1982. "Youth and the English Reformation", Past and Present 95 (May), $37-$ 67.

Cavallo, Sandra. 2014. "Family Relationships" In: Sandra Cavallo and Silvia Evangelisti (eds.), A Cultural History of Childhood and Family in the Early Modern Age. London-New Delhi-New York-Sydney: Bloomsbury, 15-32.

Delany, Paul. 1969. British Autobiography in the Seventeenth Century. London: Routledge and Kegan Paul.

Ebner, Dean. 1971. Autobiography in Seventeenth-Century England. Theology and the Self. The Hague-Paris: Nounton.

Fletcher, Anthony. 2010. Growing Up in England. The Experience of Childhood, 1600-1914. New Haven and London: Yale University Press.

Foyster, Elizabeth. 1999. Manhood in Early Modern England: Honour, Sex and Marriage. Harlow: Routledge.

Foyster, Elizabeth. 2001. "Parenting was for life, not just for childhood: The role of parents in the married lives of their children in early modern England", History 86, 313-327.

Glaser, Brigitte. 2001. The Creation of the self in Autobiographical Forms of writing in Seventeenth-Century England. Subjectivity and Self-Fashioning in Memoirs, diaries, and Letters. Heidelberg: Winter.

Houlbrooke, Ralph (ed.). 1988. English Family Life, 1576-1716. An Anthology from Diaries. Oxford: Basil Blackwell.

Houlbrooke, Ralph. 1990. The English Family 1450-1700. London-New York: Longman.

Macfarlane, Alan. 1987. Marriage and Love in England. Modes of Reproduction 1300-1840. Oxford: Basil Blackwell.

O’Day, Rosemary. 1994. The Family and Family Relationships, 1500-1900: England, France and the United States. London: Palgrave Macmillan.

Ozment, Steven. 1983. When Fathers Ruled: Family Life in Reformation Europe. Cambridge, MA and London: Harvard University Press. 
Pollock, Linda. 1983. Forgotten Children: Parent-Child Relations from 1500 to 1900. Cambridge: Cambridge University Press.

Shepard, Alexandra. 2006. Meanings of Manhood in Early Modern England. Oxford: Oxford University Press.

Stone, Lawrence. 1977. The Family, Sex and Marriage in England 1500-1800. London: Weidenfeld and Nicolson.

Keith, Thomas. 1976. "Age and Authority in Early Modern England", Proceedings of the British Academy 62, 205-248.

Umberson, Debra. 1992. "Relationships between Adult Children and Their Parents: Psychological Consequences for Both Generations", Journal of Marriage and the Family 54 (August 1992), 664-674.

Wall, Richard. 1987. "Leaving Home and the Process of Household Formation in PreIndustrial England", Continuity \& Change 2:1, 77-101.

Woods, Robert. 2006. Children Remembered. Responses to Untimely Death in the Past. Liverpool: Liverpool University Press. 